\title{
A propósito de A LITERATURA PORTUGUESA PERANTE AS REALIDADES CONTEXTUAIS LUSO-AFRO-BRASILEIRAS
}

\author{
Intervenção de ILDASIO TAVARES \\ (Professor da Universidade Federal da Bahia)
}

De inicio contesto a propriedade do título. Näo craio que se passa sobrepor o ró. tulo de Literatura Portuguosa a Lteraturas que se exprsesam em padrós culturais pro. prios, apesar de pertencerem ao mesmo sistema linglistico. E mesmo dentro da perspectiva meramente linglística há diferenças marcantes ontro o português do Brasil, da Africa e do Portugal, no medids que portencem ao mesmo sistema mas realizam.se de forma diverss, tanto léxica, como lônica, como nintaticamente. de todos a tcoria tripartida de Eugenio Coseriu, que divide uma lingua em nistema, norma e fala. Se nosso sistema \& lgual ao de Portugal, outrus normas orlentam a execuçäo de sua tala. Não fora assim e os romances de Jorge Amado, calcados na linguagem coloquial brasileira, nūo terinm que ser "traduzidos" em Portugal. E as traduçós portuguesas de pegas estrangelras nāo torlam que ser readaptadas para a encensçäo nos teatros do Brasil. Um simples exemplo mostraria a distancia sintática que há entre o portugues de Portugal e do Brastl. Para expressar uma açĭo que se processa no momento em que o lalante a executa, empregamos uma construçüo de presente mais gerúndio estamos estudando - o portugues emprega uma construçăo de presente mais prepostça mais Infinito - estamos estudar. Dlsso decorro quo ao nivel de uma lingua. gem académica denotativa a fala portuguesa $\theta$ a brasiletra so aproximam, mas ao nfial de uma linguagem literária conotativa quo redimensiono estilize a linguagem coloquial (como ocorre na prosa moderna) as duas linguas se afastam. Note-be que a ll. teratura braslletra, submetlda a Portugal por uma dicotomia do ponto do vista allenlgens e língus allenigena começa a se libertar da metropole no Romantismo, onde se definem os limites culturais e linglisticos. Primeiro, os autores romanticos voltam-so para a realidade nacional.

E mesmo que o laçm atraves do indlanismo calcado no conceito rousaeauniano do "noble sauvage"n, (concelto quo vem de multo antes de Rousseau mas tol dirundido por ele) $c$ influenciados pela llteratura indianista de Chateaubriand e James Fenimone Cooper, já o fazem com a firmo decisāo de apartar-se culturnlmente de Portugal. Acreace que ifneua tnmbém if se apartava. Alexandro Herculano, so ler os "Primeiras Cantos" de Gonçalves Dias, lez anotaçōes a margem lo livro ucusando o bardo maranheave de uma métrica "froura". E isso se deve a uma contagem de sllabas com o ouvido por- 
tuguếs de versos forjados por um brasileiro. Veja-se um cxemplo - a palarra submarinha que Herculano, como bom portugues, escandra sub-ma-ri-nha com quatro silabas e Goncalves Dlas escandia su-bi-ma-rl-nha, producindo na primeira silaba o que Manuel Bandeira chama um suarabáct, fenomeno típico da ojeriza que tem os brasileiros de terminar uma sllaba com uma consoante oclusira.

Esse processo de libertaçĩo e autonomia de nossa literatura, fugindo do colonialismo cultural português, culmina na Semana de 22, e a partir dal deline-se bem uma literattira brasileira em linguagem e expressâo cultural próprias. E Manuel Bandelra mesmo que faz uma diatribe contra o que classifica de "macaquear a sintaxe lusa".

Portanto nīo vejo como encaixar a literatura brasileira no rótulo Portuguesa. Suz expressño cultural d diversa e sua linguagem tanbem. Somente uma reviravolta colonialista e paternalista perfeitamente dispensável poderta conceber tal proposigăo.

Quanto h llteratura africana, temos um caso bem mais flagrante de um exato abismo cultural, acrescicio de uma linguagem tanto mais forte quanto calcada em signos - simbolos regionaig. Descio o século XiX uue paetas negros sentiam a rejeiçāo dor portugueses e cinglam-se aos seus valores culturais para oporem-se ao preconceito c a colonizaçāo. Caetano da Costa Alegre, poeta negro de São Tomé, canta com ferror cm seus versos algo que nenhum poeta portugués cantaria (e abrimos uma honrosa exceço para Camós em suas endechas a uma cativa na India) a beleza da mulher negra: E a literatura africana deste século é toda de contestaça aos valores culturals coionialistas e de exaltaçāo da negritude. É importante assinalar que, todo o ser humano possui dentro de sl sentimentos e Anslas cujo conteúdo latente é igual mas em cada cultura ele se expresss de torma diversa e sempre relacionada ests expressāo com o ambiente e suas vivencias. Nota-se isso bern no poeta angolano Antonio Cardoso quando produz um simlle em que diz que o seio da mulher amads tem a dureza da truta ma. boque. Ora, um simile produz força de expressio metosimica atratés da transposição da qualidade de algo so objeto que se pretende realçar. Dureza vem do segundo termo do simile, como num exemplo em portugués nosso - Seus selos sāo como a rocha - cxpressnmos dureza com um referente cultural acesofvel a qualquer falante de nossa língua. No caso do António Cardoso, a intensidade e virtualidade da comparação somente pode ser percebida par quem conhece a fruta maboque. E.nos necessário introduzir no simile a palavra dureza para que o entendamos. No entanto qualquer africano entenderá o simile e todas as outras implicaçōes sexuais que ha em se comparar seios a uma fruta. Nós perdemos a intrinsecalidade da inveação poética pois nads nos diz a fruta maboque. o que prova que nåo Interessa o contelido latente e sim a forma como ele se expressa utruvés de signos próprios a uma cultura definida, que nảo foi esmagada pelos portugueses, resistiu e ora se alga em toda a sus dignidade.

Por essas razũes preferininmos que o título fosse a literntura de Lingua Portuguesu nas realidades contertuais braslleira, africana e portuguesa, porque além do mais reunir as trés culturas numa só rubrica é violentar a individualidade de cadn uma.

NOTA - Vários dos pontos abordados neste debate foram extraidos do trabalho Some Aspects of Arican Lterature in Portuguese de Isa Maria Drummond Simós e Wulfried Peuser, Revista Afriscope, Majo, 1976. 